\title{
Synthesis and evaluation of $\alpha$-glucosidase and tyrosinase inhibitory activities of ester derivatives of usnic acid
}

\author{
Pham Duc Dung ${ }^{1}$, Duong Thuc Huy ${ }^{1}$, Nguyen Van Kieu, 2,3,*
}

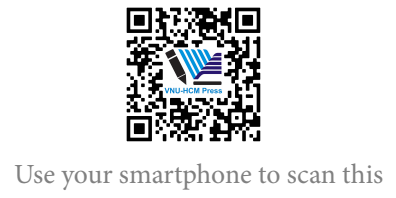

QR code and download this article
${ }^{1}$ Department of Chemistry, Ho Chi Minh City University of Education, District 5 , Ho Chi Minh City, Viet Nam

${ }^{2}$ Institute of Fundamental and Applied Sciences, Duy Tan University, Ho Chi Minh City 700000, Vietnam

${ }^{3}$ Faculty of Natural Sciences, Duy Tan University, Da Nang, 550000, Vietnam

\section{Correspondence}

Nguyen Van Kieu, Institute of Fundamental and Applied Sciences, Duy Tan University, Ho Chi Minh City 700000, Vietnam

Faculty of Natural Sciences, Duy Tan University, Da Nang, 550000, Vietnam

Email: nguyenvankieu2@duytan.edu.vn

History

- Received: 2020-03-25

- Accepted: 2020-07-12

- Published: 2020-07-27

DOI : 10.32508/stdj.v23i3.1850

\section{Check for updates}

\section{Copyright}

(c) VNU-HCM Press. This is an openaccess article distributed under the terms of the Creative Commons Attribution 4.0 International license.

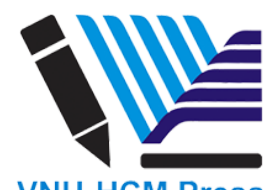

\begin{abstract}
Introduction: Usnic acid isolated from lichen was a potential bioactivity compound. It has a broad spectrum bioactivity, including antiviral, anti-inflammatory, anticancer... However, low solubility in water limited its application. Many researchs have done to overcome the restriction. Recent results showed that usnic acid derivatives bearing triazole, enamine, pyrazole and benzylidene groups had strong antiviral and anticancer activities. Thus, investigation of usnic acid derivatives synthesis was an attractive aspect due to the diversity of bioactivities of usnic acid derivatives. Methods: Usnic acid was isolated from lichen, six ester derivatives of usnic acid were synthesized from usnic acid with acetyl chloride and benzoyl chloride under stirring at room temperature. The products were evaluated $\boldsymbol{\alpha}$-glucosidase and tyrosinase inhibitory activities. Results: All the ester derivatives were created with good yields. All derivatives exhibited the same or higher activity comparing with usnic acid. Ester of usnic acid bearing benzoyl group showed excellent $\alpha$-glucosidase activity with $\mathrm{IC}_{50} 26.7 \pm 0.57$ and $68.8 \pm 0.15 \mu \mathrm{M}$. Conclusion: Among the ester derivatives, UE1 and UE6 were reported as as new compounds. Interestingly, all products displayed the same or higher biological activity than the starting material, usnic acid when evaluated against $\alpha$-glucosidase and tyrosinase. Key words: Acetyl chloride, benzoyl chloride, ester derivatives, $\alpha$-glucosidase, tyrosinase, usnic acid
\end{abstract}

\section{INTRODUCTION}

Isolated compounds from lichens exhibited a wide range of biological properties, such as antimicrobial, antiviral, anti-inflammatory, anticaner... ${ }^{1}$. Usnic acid, a dibenzofuran derivative found only in lichens was a remarkable substance. Usnic acid has a broad spectrum of bioactivity, especially against gram-positive bacteria such as Staphylococcus, Streptococcus, and antifungal ${ }^{2}$. Futhermore, it also has antiviral, anti-inflammatory, antipyretic... activities ${ }^{2}$. In vitro experiments showed that usnic acid could inhibit many human cancer cell lines growth ${ }^{3}$. However, toxicity with liver and low solubility in water of usnic acid has limited application of it in cancer treatment. This attracts interests of many researchers to overcome the limit.

The first research of usnic acid derivatives synthesis was carried out by Takai in 1979, the solubility of products were improved by preparing glycoside and imine derivatives of usnic acid ${ }^{4}$. Recently, many researchs showed that usnic acid bearing triazole, enamine, pyrazole and benzylidene groups had strong antiviral and anticancer activities ${ }^{5-8}$. The diversity of bioactivities of usnic acid derivatives showed that they could be a potential drugs in medicinal treatments.
Herein, we described a procedure of ester derivatives synthesis from usnic acid, these compounds were evaluated of $\alpha$-glucosidase and tyrosinase inhibitory activities.

\section{MATERIALS AND METHODS}

\section{Materials}

(+)-Usnic acid isolated from lichen.

Acetyl chloride, benzoyl chloride (Sigma-Aldrich).

Silica gel 60 (HiMedia, India).

Bruker Advance III (400 MHz for ${ }^{1} \mathrm{H}$ NMR and 100 $\mathrm{MHz}$ for ${ }^{13} \mathrm{C} \mathrm{NMR}$ ) spectrometer with TMS as internal standard recorded NMR spectra.

The HR-ESI-MS were recorded on a HR-ESI-MS Bruker microTOF Q-II.

Column chromatography was performed with silica gel 60 .

\section{General experimental procedure}

A mixture of (+)-usnic acid $(0.250 \mathrm{~g}, 0.727 \mathrm{mmol})$ in $\mathrm{CHCl}_{3}(5.0 \mathrm{~mL})$ was stirred at room temperature for 5 minutes. Acetyl chloride ( $0.341 \mathrm{~g}, 4.350 \mathrm{mmol})$ was added, followed by pyridine $(3.5 \mathrm{~mL}, 43.502 \mathrm{mmol})$ and stirred at room temperature for $6 \mathrm{~h}$. Then, the organic layer was extracted with water and saturated 
with aqueous $\mathrm{NaHCO}_{3}$, respectively, and dried over anhydrous $\mathrm{Na}_{2} \mathrm{SO}_{4}$. The mixture was filtered and evaporated using rotatory vacuum evaporator. The products, UE1-4 were purified by subjecting to silica gel column.

A mixture of (+)-usnic acid $(0.250 \mathrm{~g}, 0.727 \mathrm{mmol})$ in $\mathrm{CHCl}_{3}(5.0 \mathrm{~mL})$ was stirred at room temperature for 5 minutes. enzoyl chloride $(0.611 \mathrm{~g}, 4.350 \mathrm{mmol})$ was added, followed by pyridine $(3.5 \mathrm{~mL}, 43.502 \mathrm{mmol}$ ) and stirred at room temperature for $6 \mathrm{~h}$. The products, UE 5 were purified by subjecting to silica gel column. A mixture of UE3 $(0.280 \mathrm{~g}, 0.727 \mathrm{mmol})$ in $\mathrm{CHCl}_{3}$ $(5.0 \mathrm{~mL})$ was stirred at room temperature for $5 \mathrm{~min}$ utes. enzoyl chloride $(0.611 \mathrm{~g}, 4.350 \mathrm{mmol})$ was added, followed by pyridine $(3.5 \mathrm{~mL}, 43.502 \mathrm{mmol}$ ) and stirred at room temperature for $6 \mathrm{~h}$. The products, UE 6 were purified by subjecting to silica gel column.

\section{Biological activities investigation}

These inhibitory activities were evaluated according to ${ }^{9}$. Enzymatic activity was calculated by measuring absorbance at $405 \mathrm{~nm}$ (ALLSHENG micro plate reader AMR-100). All samples were analyzed in triplicate at various concentrations to obtain the $\mathrm{IC}_{50}$ value of each compound. The mean values and standard deviation were also identified.

\section{Structure determination of products}

The products were verified structures by ${ }^{1} \mathrm{H}$ and ${ }^{13} \mathrm{C}$ NMR method using $\mathrm{CDCl}_{3}$ as solvent and HR-ESIMS method.

UE1: Light yellow powder, $\mathrm{m}=0.0342 \mathrm{~g}$, yield: 10 $\% ;{ }^{1} \mathrm{H} \mathrm{NMR}\left(\mathrm{CDCl}_{3}, 400 \mathrm{MHz}\right) \delta_{H} 6.38(1 \mathrm{H}, \mathrm{s}), 2.65$ $(3 \mathrm{H}, \mathrm{s}), 2.40(3 \mathrm{H}, \mathrm{s}), 2.35(3 \mathrm{H}, \mathrm{s}), 2.23(3 \mathrm{H}, \mathrm{s}), 2.22$ $(3 \mathrm{H}, \mathrm{s}), 2.19(3 \mathrm{H}, \mathrm{s}), 2.02(3 \mathrm{H}, \mathrm{s}) .{ }^{13} \mathrm{C} \mathrm{NMR}\left(\mathrm{CDCl}_{3}\right.$, $100 \mathrm{MHz}) \delta_{C} 203.0,202.9,195.0,169.1 \mathrm{x} 2,168.5$, $151.2,147.8,145.7,145.5,144.5,121.5,120.3,115.5$, 113.7, 108.5, 47.0, 31.8, 29.5, 21.1, 20.7, 20.5, 9.7, 9.2. HR-ESI-MS m/z $[\mathrm{M}+\mathrm{H}]^{+}$calcd. for $\mathrm{C}_{24} \mathrm{H}_{23} \mathrm{O}_{10}$ : 471.1291; found: 471.1297 .

UE2: Light yellow powder, $\mathrm{m}=0.1055$ g, yield: 34 $\% ;{ }^{1} \mathrm{H} \mathrm{NMR}\left(\mathrm{CDCl}_{3}, 400 \mathrm{MHz}\right) \delta_{H} 5.90(1 \mathrm{H}, \mathrm{s}), 2.60$ $(3 \mathrm{H}, \mathrm{s}), 2.54(3 \mathrm{H}, \mathrm{s}), 2.46(3 \mathrm{H}, \mathrm{s}), 2.33(3 \mathrm{H}, \mathrm{s}), 1.98$ $(3 \mathrm{H}, \mathrm{s}), 1.81(3 \mathrm{H}, \mathrm{s}) .{ }^{13} \mathrm{C} \mathrm{NMR}\left(\mathrm{CDCl}_{3}, 100 \mathrm{MHz}\right) \delta_{C}$ 198.6, 195.0, 192.8, 190.9, 177.8, 168.9, 168.8, 153.7, $149.0,148.5,123.6,118.9,116.1,106.2,98.8,59.5$, 32.1, 31.1, 26.2, 21.4, 20.8, 10.4 .

UE3: Light yellow powder, $\mathrm{m}=0.0420 \mathrm{~g}$, yield: $15 \%$; ${ }^{1} \mathrm{H} \mathrm{NMR}\left(\mathrm{CDCl}_{3}, 400 \mathrm{MHz}\right) \delta_{H} 13.22(1 \mathrm{H}, \mathrm{s}), 5.91$ $(1 \mathrm{H}, \mathrm{s}), 2.74(3 \mathrm{H}, \mathrm{s}), 2.54(3 \mathrm{H}, \mathrm{s}), 2.45(3 \mathrm{H}, \mathrm{s}), 2.03$ $(3 \mathrm{H}, \mathrm{s}), 1.78(3 \mathrm{H}, \mathrm{s}) .{ }^{13} \mathrm{C} \mathrm{NMR}\left(\mathrm{CDCl}_{3}, 100 \mathrm{MHz}\right) \delta_{C}$ 201.9, 198.4, 193.3, 190.9, 178.1, 168.6, 163.3, 155.7,
$151.5,117.7,111.1,106.3,105.4,98.8,59.4,32.0,31.2$, 26.0, 21.4, 9.3.

UE4: Light yellow powder, $\mathrm{m}=0.0505$ g, yield: $18 \%$; ${ }^{1} \mathrm{H} \mathrm{NMR}\left(\mathrm{CDCl}_{3}, 400 \mathrm{MHz}\right) \delta_{H} 11.07(1 \mathrm{H}, \mathrm{s}), 5.97$ $(1 \mathrm{H}, \mathrm{s}), 2.66(3 \mathrm{H}, \mathrm{s}), 2.57(3 \mathrm{H}, \mathrm{s}), 2.35(3 \mathrm{H}, \mathrm{s}), 2.06$ $(3 \mathrm{H}, \mathrm{s}), 1.80(3 \mathrm{H}, \mathrm{s}) .{ }^{13} \mathrm{C} \mathrm{NMR}\left(\mathrm{CDCl}_{3}, 100 \mathrm{MHz}\right) \delta_{C}$ 201.9, 197.8, 194.0, 191.8, 179.3, 169.2, 155.5, 154.2, $149.7,117.4,110.0,109.9,105.4,98.5,59.1,32.4,32.0$, 28.0, 20.9, 8.9.

UE5: Light yellow powder, $\mathrm{m}=0.3250 \mathrm{~g}$, yield: 81 $\%$; ${ }^{1} \mathrm{H} \mathrm{NMR}\left(\mathrm{CDCl}_{3}, 400 \mathrm{MHz}\right) \delta_{H} 13.32(1 \mathrm{H}, \mathrm{s})$, $10.52(1 \mathrm{H}, \mathrm{s}), 8.01(2 \mathrm{H}, \mathrm{d}, J=8.0 \mathrm{~Hz}), 7.88(2 \mathrm{H}, \mathrm{d}, J$ $=8.0 \mathrm{~Hz}), 7.66(2 \mathrm{H}, \mathrm{t}, J=8.0 \mathrm{~Hz}), 7.53(2 \mathrm{H}, \mathrm{t}, J=8.0$ $\mathrm{Hz}), 7.46(1 \mathrm{H}, \mathrm{t}, J=8.0 \mathrm{~Hz}), 7.32(1 \mathrm{H}, \mathrm{t}, J=8.0 \mathrm{~Hz})$, $6.03(1 \mathrm{H}, \mathrm{s}), 5.43(1 \mathrm{H}, \mathrm{d}, 1.2), 5.24(1 \mathrm{H}, \mathrm{d}, 1.2), 2.65$ $(3 \mathrm{H}, \mathrm{s}), 2.12(3 \mathrm{H}, \mathrm{s}), 1.88(3 \mathrm{H}, \mathrm{s}) .{ }^{13} \mathrm{C} \mathrm{NMR}\left(\mathrm{CDCl}_{3}\right.$, $100 \mathrm{MHz}) \delta_{C} 200.9,200.5,174.0,165.1,164.5,164.0$, $163.0,157.5,156.4,143.5,134.6,133.6,130.7,130.1$, $128.9,128.5,128.4,127.9,114.6,109.8,109.2,104.0$, 101.9, 96.6, 60.7, 31.3, 31.1, 7.7.

UE6: Light yellow powder, $\mathrm{m}=0.2529 \mathrm{~g}$, yield: 71 $\% ;{ }^{1} \mathrm{H}$ NMR $\left(\mathrm{CDCl}_{3}, 600 \mathrm{MHz}\right) \delta_{H} 8.18(2 \mathrm{H}, \mathrm{d}, 8.0)$, $7.66(1 \mathrm{H}, \mathrm{t}, 8.0), 7.53(2 \mathrm{H}, \mathrm{t}, 8.0), 5.92(1 \mathrm{H}, \mathrm{s}), 2.60$ $(3 \mathrm{H}, \mathrm{s}), 2.56(3 \mathrm{H}, \mathrm{s}), 2.48(3 \mathrm{H}, \mathrm{s}) 2.04(3 \mathrm{H}, \mathrm{s}), 1.85$ $(3 \mathrm{H}, \mathrm{s}) .{ }^{13} \mathrm{CNMR}\left(\mathrm{CDCl}_{3}, 150 \mathrm{MHz}\right) \delta_{\mathrm{C}} 202.5,198.7$, $195.0,190.9,177.9,168.9,164.6,153.5,148.9,148.5$, $134.2,130.6,128.9,128.7,119.1,116.7,114.5,114.0$, 98.9, 59.6, 32.0, 29.8, 26.2, 21.5, 10.6. HR-ESI-MS m/z $[\mathrm{M}+\mathrm{Na}]^{+}$calcd. for $\mathrm{C}_{27} \mathrm{H}_{22} \mathrm{O}_{9} \mathrm{Na}$ : 513.1162; found 513.1122 .

\section{RESULTS}

Figure 1 showed esterification of usnic acid with acetyl chloride and benzoyl chloride. Six ester derivatives (UE1-6) were synthesized from usnic acid. Table 1 showed the results in the synthesis of six ester derivatives of usnic acid. Yields of the reactions using acetyl chloride or benzoyl chloride were good (> 70\%). Proposed mechanism of UE3 synthesis from usnic acid was shown in Scheme 1.

Table 2 and Table 3 summarized data of nuclear magnetic resonance spectra of these ester products. These signals demonstrated that six ester derivatives had been synthesized successfully.

$\alpha$-glucosidase and tyrosinase inhibitory activities of UE1-6 were listed in Table 4. All derivatives exhibited the same or higher activity comparing with starting material (usnic acid).

\section{DISCUSSION}

\section{Ester derivatives synthesis from usnic acid}

There are three hydroxy groups in usnic acid structure at C-3, C-8 and C-10 could be esterified. In the 
Table 2: ${ }^{1}$ H NMR data of ester derivatives

\begin{tabular}{|c|c|c|c|c|c|c|c|}
\hline Position & $\begin{array}{l}\text { Usnic acid } \\
\left(\delta_{H} J, \mathrm{~Hz}\right)\end{array}$ & $\begin{array}{l}\text { UE1 } \\
\left(\delta_{H} J, \mathrm{~Hz}\right)\end{array}$ & $\begin{array}{l}\text { UE2 } \\
\left(\delta_{H} J, \mathrm{~Hz}\right)\end{array}$ & $\begin{array}{l}\text { UE3 } \\
\left(\delta_{H} J, \mathrm{~Hz}\right)\end{array}$ & $\begin{array}{l}\text { UE4 } \\
\left(\delta_{H} J, \mathrm{~Hz}\right)\end{array}$ & $\begin{array}{l}\text { UE5 } \\
\left(\delta_{H} J, \mathrm{~Hz}\right)\end{array}$ & $\begin{array}{l}\text { UE6 } \\
\left(\delta_{H} J, \mathrm{~Hz}\right)\end{array}$ \\
\hline 1 & - & - & - & - & - & - & - \\
\hline 2 & - & - & - & - & - & - & - \\
\hline 3 & - & - & - & - & - & - & - \\
\hline 4 & $5.97 \mathrm{~s}$ & $6.38 \mathrm{~s}$ & $5.90 \mathrm{~s}$ & $5.91 \mathrm{~s}$ & $5.97 \mathrm{~s}$ & $6.03 \mathrm{~s}$ & $5.92 \mathrm{~s}$ \\
\hline 5 & - & - & - & - & - & - & - \\
\hline 6 & - & - & - & - & - & - & - \\
\hline 7 & - & - & - & - & - & - & - \\
\hline 8 & - & - & - & - & - & - & - \\
\hline 9 & - & - & - & - & - & - & - \\
\hline 10 & - & - & - & - & - & - & - \\
\hline 11 & - & - & - & - & - & - & - \\
\hline 12 & - & - & - & - & - & - & - \\
\hline 13 & $1.76 \mathrm{~s}$ & $2.02 \mathrm{~s}$ & $1.81 \mathrm{~s}$ & $1.78 \mathrm{~s}$ & $1.80 \mathrm{~s}$ & $1.88 \mathrm{~s}$ & $1.85 \mathrm{~s}$ \\
\hline 14 & - & - & - & - & - & - & - \\
\hline 15 & $2.66 \mathrm{~s}$ & $2.40 \mathrm{~s}$ & $2.54 \mathrm{~s}$ & $2.54 \mathrm{~s}$ & $2.57 \mathrm{~s}$ & $\begin{array}{l}5.43 \mathrm{~d}(1.2) \\
5.24 \mathrm{~d}(1.2)\end{array}$ & $2.56 \mathrm{~s}$ \\
\hline 16 & $2.11 \mathrm{~s}$ & $2.35 \mathrm{~s}$ & $2.46 \mathrm{~s}$ & $2.45 \mathrm{~s}$ & $2.35 \mathrm{~s}$ & $2.12 \mathrm{~s}$ & $2.48 \mathrm{~s}$ \\
\hline 17 & - & & & & & & \\
\hline 18 & $2.68 \mathrm{~s}$ & $2.65 \mathrm{~s}$ & $2.60 \mathrm{~s}$ & $2.74 \mathrm{~s}$ & $2.66 \mathrm{~s}$ & $2.65 \mathrm{~s}$ & $2.60 \mathrm{~s}$ \\
\hline $3-\mathrm{OH}$ & - & - & - & - & - & - & - \\
\hline $8-\mathrm{OH}$ & $13.29 \mathrm{~s}$ & - & - & $13.22 \mathrm{~s}$ & - & $13.32 \mathrm{~s}$ & - \\
\hline $10-\mathrm{OH}$ & $11.01 \mathrm{~s}$ & - & - & - & $11.07 \mathrm{~s}$ & $10.52 \mathrm{~s}$ & - \\
\hline $2^{\prime}$ & & $2.23 \mathrm{~s}$ & $2.33 \mathrm{~s}$ & $2.03 \mathrm{~s}$ & $2.06 \mathrm{~s}$ & - & - \\
\hline $2 "$ & & $2.22 \mathrm{~s}$ & $1.98 \mathrm{~s}$ & & - & - & $2.04 \mathrm{~s}$ \\
\hline $2^{\prime \prime \prime}$ & & $2.19 \mathrm{~s}$ & - & - & - & - & - \\
\hline $3,7^{\prime}$ & & & & & & $8.01 \mathrm{~d}(8.0)$ & $8.18 \mathrm{~d}(8.0)$ \\
\hline $3 ", 7 "$ & & & & & & $7.88 \mathrm{~d}(8.0)$ & - \\
\hline $4^{\prime}-6^{\prime}$ & & & & & & $7.66 \mathrm{t}(8.0)$ & $7.66 \mathrm{t}(8.0)$ \\
\hline $4 "-6 "$ & & & & & & $7.53 \mathrm{t}(8.0)$ & - \\
\hline 5 & & & & & & $7.46 \mathrm{t}(8.0)$ & $7.53 \mathrm{t}(8.0)$ \\
\hline $5 "$ & & & & & & $7.32 \mathrm{t}(8.0)$ & - \\
\hline
\end{tabular}




\begin{tabular}{|c|c|c|c|c|c|c|c|c|}
\hline Position & $\begin{array}{l}\text { Usnic } \\
\left(\delta_{C}\right)^{9}\end{array}$ & acid & $\mathrm{UE1}\left(\delta_{C}\right)$ & $\mathrm{UE} 2\left(\delta_{C}\right)$ & UE3 $\left(\delta_{C}\right)$ & $\mathrm{UE} 4\left(\delta_{C}\right)$ & UE5 $\left(\delta_{C}\right)$ & $\mathrm{UE6}\left(\delta_{C}\right)$ \\
\hline 1 & 198.1 & & 195.0 & 192.8 & 193.3 & 194.0 & 200.5 & 195.0 \\
\hline 2 & 105.3 & & 120.3 & 118.9 & 111.1 & 110.0 & 109.2 & 116.7 \\
\hline 3 & 191.7 & & 151.2 & 190.9 & 190.9 & 191.8 & 165.1 & 190.9 \\
\hline 4 & 98.3 & & 108.5 & 98.8 & 98.8 & 98.5 & 96.6 & 98.9 \\
\hline 5 & 179.4 & & 147.8 & 177.8 & 178.1 & 179.3 & 174.0 & 177.9 \\
\hline 6 & 155.2 & & 145.5 & 149.0 & 155.7 & 154.2 & 156.4 & 148.5 \\
\hline 7 & 101.6 & & 113.7 & 106.2 & 105.4 & 105.4 & 101.9 & 114.0 \\
\hline 8 & 163.9 & & 145.7 & 153.7 & 163.3 & 155.5 & 157.5 & 153.5 \\
\hline 9 & 109.4 & & 121.5 & 123.6 & 117.7 & 117.4 & 114.6 & 119.1 \\
\hline 10 & 157.5 & & 144.5 & 148.5 & 151.5 & 149.7 & 143.5 & 148.9 \\
\hline 11 & 103.9 & & 115.5 & 116.1 & 106.3 & 109.9 & 104.0 & 114.5 \\
\hline 12 & 59.1 & & 47.0 & 59.5 & 59.4 & 59.1 & 60.7 & 59.6 \\
\hline 13 & 7.5 & & 9.2 & 10.4 & 9.3 & 8.9 & 7.7 & 10.6 \\
\hline 14 & 200.3 & & 203.0 & 198.6 & 201.9 & 201.9 & 163.0 & 202.5 \\
\hline 15 & 27.8 & & 29.5 & 31.1 & 31.2 & 32.0 & 109.8 & 29.8 \\
\hline 16 & 32.2 & & 9.7 & 26.2 & 21.4 & 28.0 & 31.1 & 26.2 \\
\hline 17 & 201.7 & & 202.9 & 195.0 & 198.4 & 197.8 & 200.9 & 198.7 \\
\hline 18 & 31.2 & & 31.8 & 32.1 & 32.0 & 32.4 & 31.3 & 32.0 \\
\hline $1^{\prime}$ & & & 169.1 & 168.9 & 168.6 & 169.2 & 164.5 & 168.9 \\
\hline $1 "$ & & & 169.1 & 168.8 & & & 164.0 & 164.6 \\
\hline $1 " '$ & & & 168.5 & & & - & - & - \\
\hline $2^{\prime}$ & & & 21.1 & 21.4 & 26.0 & 20.9 & 127.9 & 128.7 \\
\hline $2 "$ & & & 20.7 & 20.8 & & & 128.4 & 21.5 \\
\hline $2^{\prime \prime}$ & & & 20.5 & & & - & - & - \\
\hline $3^{\prime}$ & & & & & & & 130.7 & 130.6 \\
\hline $3 "$ & & & & & & & 130.1 & - \\
\hline $4^{\prime}$ & & & & & & & 128.9 & 128.9 \\
\hline $4 "$ & & & & & & & 128.5 & - \\
\hline $5^{\prime}$ & & & & & & & 134.6 & 134.2 \\
\hline $5 "$ & & & & & & & 133.6 & - \\
\hline 6 & & & & & & & 128.9 & 128.9 \\
\hline $6 "$ & & & & & & & 128.5 & - \\
\hline $7^{\prime}$ & & & & & & & 130.7 & 130.6 \\
\hline $7 ”$ & & & & & & & 130.1 & - \\
\hline
\end{tabular}




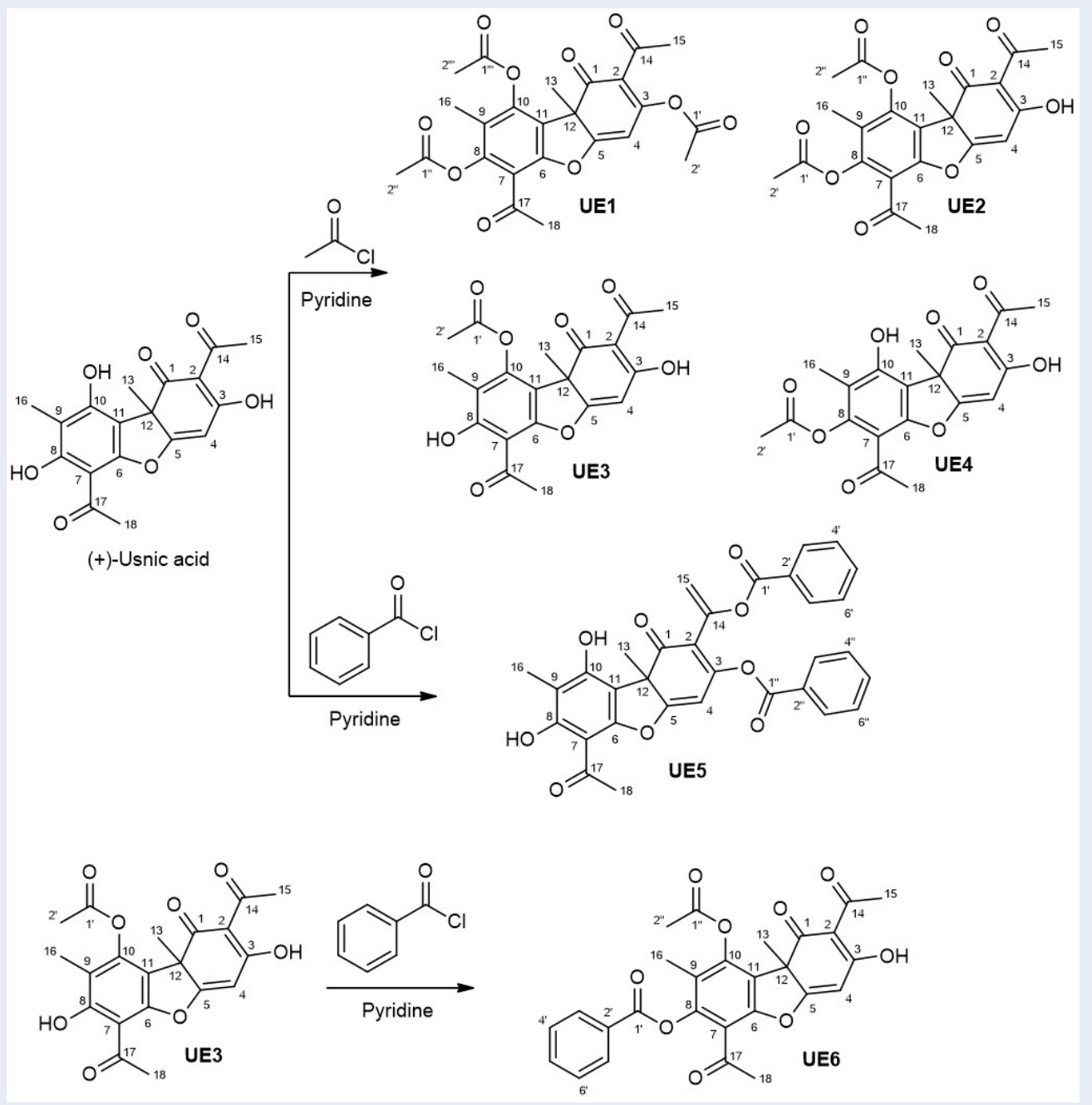

Figure 1: Esterification of usnic acid

Table 4: $\alpha$-Glucosidase and tyrosinase inhibitory activities of usnic acid derivatives

\begin{tabular}{llll}
\hline Entry & Compound & $\alpha$-Glucosidase $\mathrm{IC}_{50}(\mu \mathrm{M})$ & Tyrosinase $\mathrm{IC}_{50}(\mu \mathrm{M})$ \\
1 & UE1 & $>200$ & NA \\
2 & UE2 & $>200$ & $>200$ \\
3 & UE3 & $>200$ & NA \\
4 & UE4 & $>200$ & $>200$ \\
5 & UE5 & $26.7 \pm 0.57$ & $>200$ \\
6 & UE6 & $68.8 \pm 0.15$ & NA \\
7 & Usnic acid & $>200$ & NA \\
8 & Acarbose & $93.6 \pm 0.49$ & \\
9 & Kojic acid & & $36.1 \pm 1.07$ \\
\hline
\end{tabular}




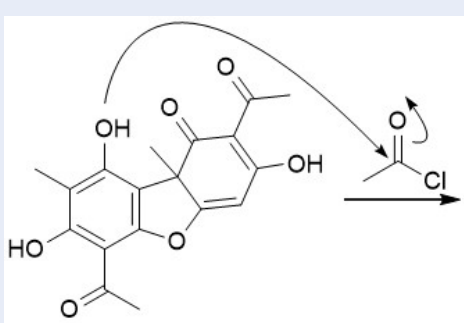

$(+)$-Usnic acid

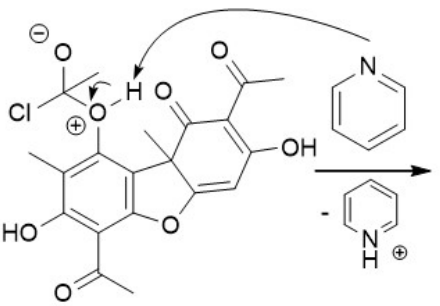<smiles>CC(=O)C1=C(O)C=C2Oc3c(C(C)=O)c(O)c(C)c(OC(C)(Cl)CO)c3C2(C)C1=O</smiles>

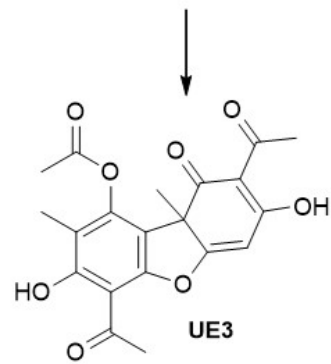

Figure 2: Proposed mechanism of UE3 synthesis from usnic acid

Table 1: Ester derivatives synthesis of usnic acid

\begin{tabular}{|c|c|c|}
\hline Entry & $\begin{array}{l}\text { Ester com- } \\
\text { pound }\end{array}$ & Yield (\%) ${ }^{a}$ \\
\hline 1 & UE1 & 10 \\
\hline 2 & UE2 & 34 \\
\hline 3 & UE3 & 15 \\
\hline 4 & UE4 & 18 \\
\hline 5 & UE5 & 81 \\
\hline 6 & UE6 & 71 \\
\hline
\end{tabular}

reaction, we use large amounts of acetyl chloride in order to react at three hydroxy groups completely. However, the reaction produced four ester derivatives (UE1-4) depending on the number and position of hydroxy groups that participated in the reaction when acetyl chloride was used as a reactant. Besides, only one product (UE5) was created when benzoyl chloride was used. Moreover, the ester product (UE6) was also generated when UE3 product reacted with benzoyl chloride in the same conditions (Figure 1). The synthesis results were listed in Table 1 below showed that yields of the reactions using acetyl chloride or benzoyl chloride were good (> 70\%).

The ${ }^{1} \mathrm{H}$ NMR spectrum of UE1 showed an olefin proton at $\delta_{H} 6.38$, and seven methyl groups at $\delta_{H}$ $2.65,2.40,2.35,2.23,2.22,2.19$ and 2.02 . The ${ }^{13} \mathrm{C}$ NMR spectrum of UE1 displayed twenty-three carbon signals, including three ketone carbons at $\delta_{C}$
203.0, 202.9 and 195.0, three carboxyl carbons at $\delta_{C}$ $169.1 \times 2$ and 168.5 , ten olefin carbons in the range of $\delta_{C}$ 155.0-100.0, one tertiary carbon at $\delta_{C} 47.0$ and seven methyl carbons at $\delta_{C} 31.8,29.5,21.1,20.7,20.5$, 9.7 and 9.2. The lack of 8 - and $10-\mathrm{OH}$ signal in usnic acid along with the appearance of seven methyl groups (usnic acid has only four methyl groups ${ }^{10}$ ) indicated the esterification reaction occurred on 3-, 8-, and $10-\mathrm{OH}$ of usnic acid. Thus, UE1 is established as 3,8,10-triacetoxyusnic acid.

The ${ }^{1} \mathrm{H}$ NMR spectrum of UE2 showed an olefin proton at $\delta_{H} 5.90$, and six methyl groups at $\delta_{H} 2.60$, $2.54,2.46,2.33,1.98$ and 1.81. The lack of both of 10 $\mathrm{OH}$ and $8-\mathrm{OH}$ in usnic acid along with the appearance of only two acetoxycarbonyl groups $\left(\delta_{H} 2.33\right.$ and $1.98 ; \delta_{C} 168.9$ and 168.8) indicated the esterification reaction occurred on both of $10-\mathrm{OH}$ and 8 $\mathrm{OH}$ of usnic acid. Thus, the structure of UE2, 8,10$O$-diacetylusnic acid ${ }^{10}$, is elucidated as shown in Figure 1 .

The ${ }^{1} \mathrm{H}$ NMR spectrum of UE3 showed a singlet of hydroxy chelated signal at $\delta_{H} 13.22$, an olefin proton at $\delta_{H} 5.91$, and five methyl groups at $\delta_{H} 2.74,2.54$, $2.45,2.03$, and 1.78. Similar to UE2, the lack of $10-\mathrm{OH}$ in usnic acid ${ }^{10}$ along with the appearance of only one acetoxycarbonyl group $\left(\delta_{H} 2.03, \delta_{C} 168.6\right.$ and 26.0) indicated the esterification reaction occurred on 10 $\mathrm{OH}$ of usnic acid. Thus, the structure of UE3, 10-Oacetylusnic acid ${ }^{11}$, is elucidated as shown in Figure 1. The examination of the ${ }^{1} \mathrm{H}$ and ${ }^{13} \mathrm{C}$ NMR spectra of UE4 revealed the similar spectra to those of UE3, excepted for the lack of $8-\mathrm{OH}$ and the occurrence of 
$10-\mathrm{OH}$ that indicated the reaction occurred at $8-\mathrm{OH}$. Thus, UE4, 8-O-acetylusnic acid ${ }^{11}$, is established as shown in Figure 1.

The ${ }^{1} \mathrm{H}$ NMR of UE5 displayed the presence of two chelated hydroxyl groups at $\delta_{H} \quad 13.32$ and 10.52 , ten aromatic protons at $\delta_{H} 7.00-8.50$, three olefin protons at $\delta_{H} 6.03,5.43$, and 5.24, and three methyl groups at $\delta_{H} 2.65,2.12$ and 1.88 . Comparison with those of usnic acid indicated the hydroxyl groups at $\delta_{H} 13.32$ and 10.52 belonging to $8-\mathrm{OH}$ and $10-\mathrm{OH}$, respectively. Moreover, the appearance of ten aromatic protons at $\delta_{H} 7.00-8.50$ ppm along with a couple gem olefin proton at $\delta_{H}$ $5.43(1 \mathrm{H}, \mathrm{d}, J=1.2 \mathrm{~Hz})$ and $5.24(1 \mathrm{H}, \mathrm{d}, J=1.2$ $\mathrm{Hz}$ ) implied the disubstitution on C-14 and C-3. Finally, UE5 is established as benzoic acid 1-(6acetyl-3-benzoyloxy-7,9-dihydroxy-8,9b-dimethyl-

1-oxo-1,9b-dihydro-dibenzofuran-2-yl)-6inyl ester as shown in Figure $1^{11}$.

The ${ }^{1} \mathrm{H}$ NMR spectrum of UE6 showed five aromatic protons at $\delta_{H} 8.5-7.5$, that implied monobenzoyl chloride reacted with UE3. A singlet signal at $\delta_{H} 5.86(1 \mathrm{H}, \mathrm{s})$, belonging to $\mathrm{H}-4$ in starting material, and five methyl groups at $\delta_{H} 2.60,2.56,2.48$, 2.04 and 1.85 . The examination of the ${ }^{13} \mathrm{C}$ NMR spectrum revealed some important structural differences from UE3 including the occurrence of five aromatic carbons at $\delta_{C} 134.2,130.6 \times 2$ and $128.9 \times 2$ confirmed the addition of monobenzoyl chloride. Moreover, the lack of chelated hydroxyl proton $8-\mathrm{OH}$ at $\delta_{H} 13.22$ (UE3) identificated that the reaction occurred at 8OH. Finally, the structure of UE6 was established as shown in Figure 1.

\section{Biological activities of usnic acid deriva- tives}

Six usnic acid derivatives including via esterification (UE1-6) were further tested with $\alpha$-glucosidase and tyrosinase inhibitory activities. From the results, all derivatives exhibited the same or higher activity comparing with starting material (usnic acid: $>200 \mu \mathrm{M}$ and no activity (NA) for $\alpha$-glucosidase and tyrosinase, respectively). Especially, UE5 and UE6 showed excellent $\alpha$-glucosidase activity with $\mathrm{IC}_{50} 26.7 \pm 0.57$, and $68.8 \pm 0.15 \mu \mathrm{M}$, respectively. These compounds not only displayed higher activity than that of usnic acid, but also with that of a positive control, acarbose ( $\mathrm{IC}_{50}$ : 93.6 $\pm 0.49 \mu \mathrm{M})$ as shown in Table 4 . In this case, UE5 displayed the strongest activity ( $\mathrm{IC}_{50}: 26.7 \pm 0.57$ $\mu \mathrm{M})$.

\section{CONCLUSION}

From usnic acid, six derivatives were synthesized via esterification reactions (UE1-6). Their chemical structures were elucidated by NMR and HRESIMS as well as comparison with those from literature. Among them, UE1 and UE6 were reported as as new compounds. Interestingly, all products displayed the same or higher biological activity than the starting material, usnic acid when evaluated against $\alpha$-glucosidase and tyrosinase. In the $\alpha$-glucosidase assay, UE5 and UE6 showed excellent activity ( IC $_{50}$ $26.7 \pm 0.57$, and $68.8 \pm 0.15 \mu \mathrm{M}$, respectively). On the other hand, all tested compounds revealed weak or no inhibitory activity in the tyrosinase assay.

\section{ABBREVIATIONS}

${ }^{1} \mathrm{H}$ NMR: Proton nuclear magnetic resonance;

${ }^{13}$ C NMR: Carbon-13 nuclear magnetic resonance; s: singlet;

d: doublet;

t: triplet.

\section{CONFLICTS OF INTEREST}

The authors declare that they have no competing financial interest.

\section{AUTHOR CONTRIBUTION}

All authors contributed in conducting experiments, acquisition of data, interpretation of data, searching the bibliography and gave final approval of the manuscript to be submitted.

\section{ACKNOWLEDGEMENT}

The authors are indebted to Dr. Warinthorn Chavasiri and Mrs. Asshaima Paramita Devi (Center of Excellence in Natural Products Chemistry, Department of Chemistry, Faculty of Science, Chulalongkorn University, Thailand) for performing the enzyme inhibitory against $\alpha$-glucosidase and tyrosinase.

\section{REFERENCES}

1. Boustie J, Tomashi S, Grube M. Bioactive lichen metabolites: alpine habitats as an untapped source. Phytochemistry Review. 2011;10:287-307. Available from: https://doi.org/10. 1007/s11101-010-9201-1.

2. Muller K. Pharmaceutically relevant metabolites from lichens. Applied Microbiology and Biotechnology. 2001;56:916. PMID: 11499952. Available from: https://doi.org/10.1007/ s002530100684.

3. Podterob AP. Chemical composition of lichens and their medical applications. Journal of Pharmaceutical Chemistry. 2008;42:582-588. Available from: https://doi.org/10.1007/ s11094-009-0183-5.

4. Takai M, Uehara Y, Beisler JA. Usnic acid derivatives as potential antineoplastic agents. Journal of medicinal chemistry. J Med Chem. 1979;22:1380-1384. PMID: 160461. Available from: https://doi.org/10.1021/jm00197a019. 
5. Bazin MA, Lamer ACL, Delcros JG, Rouaud I, Uriac P, Boustie J, et al. Synthesis and cytotoxic activities of usnic acid derivatives. Bioorganic \& Medicinal Chemistry. 2008;16:6860-6866. PMID: 18558490. Available from: https://doi.org/10.1016/j. bmc.2008.05.069.

6. Sokolov DN, Zarubaev VV, Shtro AA, Polovinka MP, Luzina $\mathrm{OA}$, Komarova $\mathrm{Nl}$, et al. Anti-viral activity of (-)- and (+)usnic acids and their derivatives against influenza virus $A$ (H1N1) 2009. Bioorganic Med Chem Lett. 2012;22:7060-7064. PMID: 23099095. Available from: https://doi.org/10.1016/j. bmcl.2012.09.084.

7. Shtro AA, Zarubaev VV, Luzina OA, Sokolov DN, Kiselev OI, Salakhutdinov NF. Novel derivaties of usnic acid effectively inhibiting reproduction of influenza A virus. Bioorganic \& Medicinal Chemistry. 2014;22:6826-6836. PMID: 25464881. Available from: https://doi.org/10.1016/j.bmc.2014.10.033.

8. Vanga NR, Kota A, Sistla R, Uppuluri M. Synthesis and antiinflammatory activity of novel triazole hybrids of $(+)$-usnic acid, the major dibenzofuran metabolite of the lichen Usnea longissima. Mol Divers. 2017;21:273-282. PMID: 28130662. Available from: https://doi.org/10.1007/s11030-016-9716-5.

9. Ramadhan R, Phuwapraisirisan P. New arylalkanones from Horsfieldia macrobotrys, effective antidiabetic agents concomitantly inhibiting $\alpha$-glucosidase and free radicals. Bioorganic \& medicinal chemistry letters. 2015;25(20):4529-4533. PMID: 26343830. Available from: https://doi.org/10.1016/j. bmcl.2015.08.069.

10. Nguyen KV, Nguyen KPP, Sangvichien E, Wonganan $P_{i}$ Chavasiri W. Chemical constituents of the lichen Usnea baileyi (Stirt.) Zahlbr. Tetrahedron Letters. 2018;59:1348-1351. Available from: https://doi.org/10.1016/j.tetlet.2018.02.007.

11. Erba E, Pocar D, Rossi LMJIF. New esters of R-(+)-usnic acid. IL Farmaco. 1998;53:718-720. Available from: https://doi.org/10. 1016/S0014-827X(98)00113-X. 